\title{
FROM KANT TO RAYMOND WILLIAMS An Outlook of Western European Cultural Policy*
}

\author{
Gil Fesch \\ Institute of Sociology, University of Porto, Portugal
}

\begin{abstract}
The present work aims at contributing to a better understanding of current trends in cultural policies. We shall start by providing an outlook of general tendencies in European cultural policy, emphasizing the developments at work during the second half of the XX century. By deconstructing the principles inherent to the (taken-for-granted) policy programs, we will then try to cast light on the upcoming challenges for contemporary cultural policy regimes.
\end{abstract}

Keywords: Sociology of Culture; Western European Cultural Policy; Cultural Studies.

\section{Introduction}

Cultural policy, though a recent area of public policy-making in Western European states, developed significantly in the last decades. Conceived in the postwar context, most cultural policy programs, in their genesis, reified the opposition between legitimate and non-legitimate art forms - most generally consisting of a tripartite core of action including "historical heritage, support of professional artists, and traditional cultural institutions" (Dubois, 2014: 5).

Public debates later came to question hierarchical conceptions of art and culture, claiming for the promotion of diversity in contemporary public policies. Thus being, cultural policy regimes progressively started to encompass a wide array of activities in which youth and local cultures, among others, play a major role - intertwining art and entertainment, as creative industries took the lead (Silva et al., 2012).

Underlying such changes are different notions of culture itself, with concrete implications. As a widespread tendency, Donnat (2003) mentions a move towards noncultural purposes in cultural policies from 1980 onwards, namely social integration and economic development. Public expenditure on culture, therefore, becomes all the more

\footnotetext{
* Paper developed under the PhD Scholarship SFRH/BD/98258/2013, granted by the Portuguese Foundation for Science and Technology.
} 
defined according to economic rather than aesthetic rationales, i.e. cultural institutions are envisioned qua investments with economic impacts.

Far from meaning the end of legitimist approaches, such shift points to a growing complexity in contemporary policy practices, in which contradictory logics and objectives coexist (Gomes \& Lourenço, 2009). In times of severe financial crisis, it is with no surprise that the public funding of elite culture manifestations - especially contemporary high art music and experimental music ${ }^{1}$ - ends up facing critiques for hardly meeting the demands of general audiences (Dubois, 2011).

\section{The advent of cultural policy in Europe}

Following Teixeira Lopes' (2000) claim for a prudent return to the foundations of debates concerning cultural phenomena, ${ }^{2}$ it is pertinent to start by dissecting the ideological issues at stake in early cultural policy-making, of which the Malrucian ${ }^{3}$ program might be illustrative.

During the 1960s, the cultural cause (Donnat, 2003: 11) was in its heyday. Though the situation was far from homogenous, European cultural states asserted their "relative weight and symbolic authority" (Dubois, 2014: 6) in determining artistic classifications, sticking to the belief that access to art and culture was an unequivocal prerequisite to full citizenship. Accordingly, the main goal of public expenditure was to render access to the masterpieces of high culture, i.e. reaching the universality of art. The critical issue, though, was the way in which such an objective was distilled into concrete measures.

Donnat sharply calls into question Malraux's "entreprise de démocratisation", pointing to the ambiguity of his cultural policy program. What does it mean to "rendre accessible les grandes ceuvres de l'art et de l'esprit" (apud Donnat, 2003: 10)? Two possibilities spring up. First, if we consider accessibility in a literal way, it would imply a strategy of equal distribution - in territorial terms - of cultural equipment, possibly via low-fare cultural events. On the other hand, and if we take the term in its ontological sense, it could also mean designing cutting-edge programs for to act on the production of desire itself, as means of attenuating social inequalities in access to culture.

\footnotetext{
${ }^{1}$ Such classifications, to a certain extent, perpetuate hierarchical distinctions that we seek to overcome. For the remainder of the present work, we shall adhere to the term new music.

${ }^{2}$ Whenever building a theoretical itinerary, Teixeira Lopes (2000: 28) stresses the importance of dodging second-hand interpretations - and possible misconstructions - as means of better replicating intrinsic conflicts. This is all the more valid when dealing with symbolic phenomena.

3 André Malraux (1901-1976) was a French novelist, theorist and, most notably, the first Minister of Cultural Affairs of France (1959-1969).
} 
Among the proponents of the cultural cause, the task was an ambitious one. It meant, at once, increasing the number of high-art practitioners and modifying the sociodemography of audiences - in other words, attracting newcomers while seeking to turn them into regular concertgoers. These goals, however, were far from complementary (if not contradictory), especially if we consider the symbolic issues inherent to cultural phenomena. But more: regardless of such aspirations, Malraux's concrete policy measures paradoxically reflected geographic rather than social concerns, as shown by its main focus on the decentralization of cultural institutions (Donnat, 2003). For this reason, Bourdieu criticized him for simply opening up cultural institutions by providing free access to events - so as to make "universal culture universally accessible" (apud Bennett, 2011: 540)4.

The French cultural policy regime - and analogously other European regimes at the time -, thus, helped crystallize the dichotomy between elite and mass cultures. Subjacent to the conflict was a cultural actualization, via Kant's notion of 'pure taste', of evolutionary assumptions, such as the knitting oppositions 'primitive/civilized', 'body/soul', but also 'nature/culture' (Bennett, 2011: 536). This was particularly noticeable in public debates during the 1960s, in France, as the Ministry of Culture asserted its legitimism and vindicated its symbolic role as gatekeeper of artistic recognition and labeling (Dubois, 2011).

It was in this sense that cultural policy made its way into the reproducing of cultural domination (though watered down by a proactive discourse, claiming to promote artistic evolution through democratization processes). By paying tribute to a certain asceticism, or immateriality in aesthetic judgment, such programs actively shrank the dominated culture to its mere functional dimension - the 'choice of the necessary', to use Bourdieu's account of the working-class culture (Bennett, 2011). Little space (or none at all) was left to 'bodily manifestations', all too readily deemed as inauthentic, frivolous, superficial or commercial, somehow perpetuating the antithesis of art and money.

So being, early cultural policy-making sought to promote cultural forms akin to Benjamin's concept of aura - unique for its "embeddedness in the context of tradition" (2010: 16). In Kantian terms, abstract judgment and aesthetic distancing outweighed subordination to use and popular involvement. Relational appreciation of form and

\footnotetext{
4 For a critical analysis on the debates concerning the role of sociology in cultural policy-making, vide Dubois, Vincent (2011). Cultural capital theory vs. cultural policy beliefs: How Pierre Bourdieu could have become a cultural policy advisor and why he did not. Poetics. pp. 491-506.
} 
discursive intricacy muted even those "sensory excesses" of popular culture that could ultimately be seen as powerful critiques of 'pure taste' (Bennett, 2011: 535).

Here we find unmistakable echoes of Adorno's arguments on the uprising of culture industries:

The concept of technique in the culture industry is only in name identical with the technique in works of art. In the latter, technique is concerned with the internal organization of the object itself, with its inner logic. In contrast, the technique of the culture industry is, from the beginning, one of distribution and mechanical reproduction, and therefore always remains external to its object (Adorno, 1975: 14).

Disinterested pleasure, hence, was the utmost value - the path to universal communicability ${ }^{5}$. Kant's influence (and, by kinship, Bourdieu's), "so far as its translation into distinctive politico-aesthetic programmes is concerned", can be traced as follows:

The conditions Kantianism generates for such programmes are that (i) the universality of the aesthetic must be projected as a goal to be accomplished, (ii) there must be agents of transition that can distil this universality in advance of its accomplishment and so serve as a conduit to it, (iii) the failure to judge competently must be accounted for in terms of a deficit in the make-up of the subject, and (iv) that such deficits can therefore only be overcome th[r]ough the actions of some other agent (Bennett, 2011: 540).

To summarize it, Dubois (2014: 9) enunciates a trilogy of shared policy rationales in Western European cultural policy, already alluded to at the beginning of the present work. The first one relates to the "preservation of artistic and historic heritage", which could be seen as the driving force of early policy-making in the field. Next, and intimately connected to it, Dubois mentions the "support for artistic creation". Underlying this rationale is the idea that the market, by itself, is insufficient when it comes to promoting artistic innovation - though in some cases these actions have also been attacked for constituting an abusive state interference, which is why many cultural policy regimes came to delegate aesthetic judgment to semi-independent cultural institutions. The last one, in its turn, has to do with equality in access to education, culture, and art. Highly ambitious, this latter rationale reflects what could be seen as a humanist concern, linking democracy and culture in the quest for full citizenship. Though it was never fully accomplished, this was a structural goal in early cultural

5 For a critique, vide Vandenabeele, Bart (2012). Beauty, disinterested pleasure, and universal communicability: Kant's response to Burke. KANT-STUDIEN. Vol. 103. No. 2. pp. 207-233. 
policy regimes, bridging Enlightenment values and postwar concerns - the welfare state.

\section{Reconsidering Culture}

As cultural democratization, the main goal and legitimation of early cultural policy regimes - even in the most liberal, non-interventionist states - , started to lose its strength as guiding principle, there was a progressive move towards the promotion of cultural diversity. This is not to say, as mentioned before, that the legitimist approach is no longer predominant, but simply to acknowledge that cultural policy programs are conceived in a more "participatory way" (Dubois, 2014: 11). The French case, again, might be of assistance.

Counter-cultural movements in the late 1960 s began to attack the "founding myth" of cultural democratization (Dubois, 2014: 13) for favoring heritage preservation - be it material or immaterial -, resulting in a wider consensus on the need for reconsidering public policy practices from a bottom-up perspective. Surely there had been an amelioration of the conditions of living for artists, bigger support to creation and cultural institutions, and a (consequently) richer artistic environment, yet with no significant results in overcoming inequalities in access to culture (Gomes \& Lourenço, 2009).

It was in this context that Lang' assumed the task of revitalizing cultural policy in France. Though he did not fully abandon the initial project, there was an obvious approximation to alternative cultural manifestations, envisioned as a necessary complement to it. No longer was there a clear-cut opposition between major and minor cultures, but rather a questioning of canonical hierarchies, as culture industries and youth cultures fought to break the consensus around (high) art as the universal goal. So understood, the similarities with phenomenological approaches become self-evident: there is no reason for granting ontological superiority to the great aesthetic experience. Such objectified manifestations, regardless of their importance, flow pari passu with its relational, intersubjective counterpart - culture as an ongoing process, continuously instantiated in everyday practice (Teixeira Lopes, 2000).

The term cultures populaires, thus, referred to "positive and sometimes mythical aspects like spontaneity, authenticity, links to real life and in fact everything that elites view as a kind of popular "paradise lost"' (Dubois, 2011: 396). Furthermore, Lang's

\footnotetext{
${ }^{6}$ Jack Lang ( $\left.{ }^{*} 1939\right)$ is a French politician (member of the Socialist Party) best known for having served as Minister of Culture (1981-1986 and 1988-1992), but also as Minister of Education (1992-1993 and 20002002).
} 
detachment from its predecessor's hierarchical conception of culture is most evident in the usage of the concept of développement culturel, implying an ambitious project of societal transformation, via culture, in which infra-cultural forms are gradually legitimized and integrated.

The abovementioned casts light on a profound resignification of the notion of culture itself, unraveling the multiple (and fuzzy) dimensions that Raymond Williams (1963) tried to systematize. Accordingly, culture can no longer be seen as exclusively referring to the realm of the arts. Though this is surely one of its main implications, stress should be put on accounting culture for its anthropological dimension, manifested in lifestyles and self-presentation, but also for its role as a lever of development, economic growth and social integration (apud Anico, 2009)7.

More than a mere change in terms of theoretical standpoint towards culture, Jack Lang's Ministry took the hard task of translating these values into concrete actions. Contrary to Malraux's democratization program, which sought to put audiences and works of art under direct, unmediated contact, Lang realized the need for alternative perspectives and, so, put into motion a strategy that took advantage of culture industries - in a way anticipating new modes of appropriation, boosted by forthcoming technological transformations (Donnat, 2003) ${ }^{8}$.

During the 1980s, the democratization project, thus, consisted of a strategy of rapprochement between culture and fest (Donnat, 2003: 15), aiming to go beyond conventional circuits of cultural activities, as means of extending cultural participation to social strata otherwise excluded. This perspective, though far from systematic, led withal to the creation of numerous outdoor events, festivals and tours - Fête de la Musique, Fête du Cinéma, Journées du Patrimoine, among other massive celebrations -, in the quest for more relaxed approaches to culture. Underlying Lang's agenda was the awareness of the need to act on the conditions of reception, through mediation processes and education programs, in order to desacralize elite culture.

Regardless of their ethos, 'cultural animation' policies were highly criticized, with Bourdieu at the forefront, for "merely confirming the dispossession of the dispossessed by locking them into the consumption of inferior and subordinate cultural forms"

\footnotetext{
7 Weber's (1998) account of the historical process of secularization of music - and, analogously, art - can be of interest here, by providing early hints on the forthcoming dilatation of the notion of culture.

8 Vide Hennion, Antoine (2001). Music Lovers. Taste as Performance. Theory, Culture, Society. Vol. 18. No. 5. pp. 1-22. Here, Hennion proposes a dignifying perspective on the dynamics of taste - an opportunity to discover oneself and to affirm one's personality - as opposed to the idea of a passive, subservient listener.
} 
(Bennett, 2011: 540). For this reason, we find in his late writings a strong vindication of high culture, the ultimate bulwark against the market:

Bourdieu's new conception of the universality of culture's ascesis corresponds with Adorno's insistence on the autonomy of culture from the economy's purposefulness. In both thinkers, autonomous high culture stands as a token of potential freedom in a world of human subjection to material production. By providing a model of activity beyond the inequality and oppression of the economy, autonomous art provides an implicit critique of these injustices, bringing them to consciousness and thereby making possible their subjection to willful action (Gartman, 2012: 54).

Promoting popular culture would then be misleading on the account that those tastes are not tradable forms of cultural capital, ultimately converting deprivation into an elective choice - cultural policy had made its way into the economy of spectacle (Debord, 1967).

Manipulation of 'low' cultural forms, however, was far from being an exclusive feature of Lang's Ministry. In fact, Dubois (2011) goes on to detect five overlapping attitudes or strategies - common to many policy regimes - towards popular cultures. The first one has to do with neglect or ignorance, which is consistent with early cultural policy practices outlined before, though it remains, to a certain extent, still valid. Second, and starting from the 1980 , it is also possible to find programs that make an indirect use of popular culture, trying to lure people and bring them closer to elite art forms and institutions. A similar kind of symbolic manipulation, usually connected to other policy fields, can then be traced in policies that aim at promoting social integration through popular cultures. The fourth one, by its turn, consists of an aesthetic promotion of 'low' cultural forms, more often forcing them to conform to the rules of the musical establishment, rather than accepting them per se - in other words, a sort of "cultural hijacking" (Dubois, 2011: 399). The last strategy mentioned is 'museification', according to which popular culture is detached from its context and used for the sake of elite culture's interests - via objectification of otherwise more volatile cultural forms, now emptied of their meaning and subversive potential.

The emancipation of popular culture, it follows, was never fully achieved, though important steps were taken. It is clear that 'low' cultural forms did not succeed in establishing their own logics and values in a satisfactory way, but there was surely a questioning of hierarchies and a growing awareness of the need to assess culture in its multiplicity, as means of defying cultural domination. As a general tendency, it is possible to mention a shift towards more inclusive cultural policy-making, though 
legitimism still prevailed, and a progressive decentralization - state institutions maintain their role as artistic gatekeepers and local authorities intercede for intermediate cultural forms and local traditions. Interestingly enough, such (relative) appraisal of popular culture is particularly evident in dance and music, whereas theater and visual arts remain somehow more attached to a legitimist perspective (Dubois, 2011).

\section{Current trends and challenges}

Although we referred mostly to the French case, the sketch outlined so far is no less valid for the remainder of the European context. Despite obvious national distinctions, the progresses and transformations we sought to portray, but also the hesitations, ambiguities and paradoxes, relate to a core of action that is common to most (if not all) Western European cultural policy regimes.

The original trilogy of objectives that constituted the base of cultural policy-making preservation of artistic and historical heritage, support for artistic creation and equal access to culture - are now combined with non-cultural purposes. Contrary to early moments, the search for national prestige and influence at the international level, the articulation with social policy goals (e.g. urban regeneration through gentrification processes and alleviation of social exclusion), as well as the will to capitalize cultural investments in terms of touristic attractiveness, have led to a deep restructuring of cultural policies (Anico, 2009).

Here we find evidence of what Donnat (2003: 14) calls the reconciliation of culture and economy, i.e. cultural policy regimes that act on the realm of culture industries, though still recognizing the need to support and protect art from the inner logic of the market. Ergo, creativity becomes the key notion in cultural policy-making, as arts lose their specificity by blurring with entertainment, and contemporary cultural policy programs become all the more defined by economic rather than aesthetic rationales (Dubois, 2014).

In a context of austerity, it comes with no surprise, then, that elite cultural forms, of which new music and contemporary art are the main targets, get debated in the media for receiving large amounts of money while attracting only a small audience 9 . In fact, and despite all the developments stated until now, the notion that culture by itself is a legitimate area of public support is still far from consensual. But are these reasonable

9 Despite the topicality of the matter, such discussions resonate concerns already found in early texts. In Who cares if you listen? (1958), for instance, Milton Babbitt stresses the high level of specialization required to appreciate this art form, ultimately implying that the isolation between contemporary music and audiences is an inevitable - and perhaps desirable - consequence. 
judgments? Do they reflect legitimate concerns towards public expenditure or simply meet populist, liberal rhetoric?

To a certain extent, and although most cultural policy regimes include a comprehensive set of funding modes, public opinion comes to identify them almost exclusively with financial support for arts and culture. Public budgets for state-controlled institutions and subsidies to artistic creation certainly constitute one of their main facets, but contemporary cultural policies also feature indirect ways of funding, such as social security benefits for artists and tax incentives for patronage (Dubois, 2014).

All in all, Western European cultural policy seems to face a muddy, challenging context. As a matter of fact, Donnat (2003) goes on to mention a triple crisis in cultural policies, consisting of administrative issues, as states failed to adapt to the multiple dimensions of culture; budget problems, the result of decades of accumulated expenditure on cultural institutions, leaving few space for individual subventions; and ideological dilemmas, due to (sometimes) conflicting goals and the subsequent need to question priorities. "Against a backdrop of a marked slowdown in public policies, retraction of the welfare state, [and] enhancement of markets and civil societies", governance issues come under the spotlight, as cultural policies face the ongoing process of redefining culture and the constant changes in the modes of appropriation (Silva et al., 2012: 19).

\section{References}

Adorno, Theodor W. (1975) "Culture Industry Reconsidered”. New German Critique. No. 6. pp. 12-19.

Adorno, Theodor W. (1991) The Culture Industry. New York: Routledge.

Anico, Marta (2009) "Políticas da Cultura em Portugal e Espanha". Pasos Revista de Turismo y Patrimonio Cultural, Vol. 7, No. 1, pp. 57-71.

Babbitt, Milton (1958) “Who Cares if You Listen?”. High Fidelity, Vol. 8, No. 2.

Benjamin, Walter (2010) "The Work of Art in the Age of its Technological Reproducibility”. Grey Room, No. 39, pp. 11-37.

Bennett, Tony (2011) "Culture, choice, necessity: A political critique of Bourdieu's aesthetic”. Poetics, Vol. 39, pp. 530-546. 
Bourdieu, Pierre (1984) Distinction: a Social Critique of the Judgement of Taste. Massachusetts: Harvard University Press.

Debord, Guy (1967) La Société du Spectacle. Paris: Éditions Buchet-Chastel.

Donnat, Olivier (2003) "La question de la démocratisation dans la politique culturelle française”. Modern \& Contemporary France, Vol. 11, No. 1, pp. 9-20.

Dubois, Vincent (2011) "Lowbrow culture and French cultural policy: the socio-political logics of a changing and paradoxical relationship". International Journal of Cultural Policy, Vol. 17, No. 4, pp. 394-404.

Dubois, Vincent (2014) "Cultural Policy in Western Europe". International Encyclopedia of the Social \& Behavioral Sciences, 2nd Edition. Elsevier.

Gartman, David (2012) "Bourdieu and Adorno: Converging Theories of Culture and Inequality”. Theor Soc, Vol. 41, pp. 41-72.

Gomes, Rui Telmo \& Lourenço, Vanda (2009) Democratização Cultural e Formação de Públicos: Inquérito aos "Serviços Educativos" em Portugal. Lisboa: Observatório das Actividades Culturais.

Kant, Immanuel (1998 [1790]) Crítica da Faculdade do Juízo. Lisboa: Imprensa Nacional-Casa da Moeda.

Lima dos Santos, Maria de Lourdes (2007) Políticas Culturais em Portugal. Paper presented at the V Campus Euroamericano de Cooperação Cultural, Almada.

Santos, Helena (2003) "A propósito dos públicos culturais: uma reflexão ilustrada para um caso português”. Revista Crítica de Ciências Sociais, No. 67, pp. 75-97.

Silva, Augusto Santos (2007) "Como abordar as políticas culturais autárquicas? Uma hipótese de roteiro”. Sociologia, Problemas e Práticas, No. 54, pp.11-33.

Silva, Augusto Santos; Babo, Elisa Pérez \& Guerra, Paula (2012) "Cultural policies and local development: the Portuguese case”. VII International Conference on Cultural Policy Research, 9-12 July.

Teixeira Lopes, João (2000) "Itinerário teórico em torno da produção dos fenómenos simbólicos”. Revista da Faculdade de Letras. Sociologia, Vol. 10, pp. 27-78.

Williams, Raymond (1985) Culture and Society 1780-1950. Middlesex: Penguin Books. 
Gil Fesch is a Portuguese guitarist specializing in contemporary music and a researcher in the field of sociology of music (Institute of Sociology, University of Porto). Gil holds a BA in classical guitar (Escola Superior de Música, Artes e Espectáculo, Porto) and MAs in musical performance and specialized musical performance (Hochschule für Musik Basel, Switzerland). Current projects include his PhD in sociology, supported by the Portuguese Foundation for Science and Technology, and a documentary on Helmut Lachenmann. gilfesch@gmail.com 